\author{
PIOTR BERING \\ Instytut Filologii Klasycznej, Uniwersytet im. Adama Mickiewicza w Poznaniu \\ ul. Fredy 10, 61-738 Poznań \\ Polska - Poland
}

\title{
PRZYJAŹŃ W ŻYCIU I TWÓRCZOŚCI KLEMENSA JANICKIEGO
}

\begin{abstract}
Bering Piotr, Przyjaźn w życiu i twórczości Klemensa Janickiego (Friendship in life and literary output of Klemens Janicki).

The present paper focuses on friendship's role in life and poetry of Klemens Janicki (1516-1543). Unfortunately there is a noticeable lack of sources and testimonies. The analysis of poetical works written by Janicki is only partially useful. In the epoch of the Renaissance very often the statements on friendship were exaggerated. Despite of these circumstances it is possible to analyze the poetical techniques used in texts about friends and friendship. The paper ends with an attempt to describe the nature of Ianicius' relationships with his friends.
\end{abstract}

Keywords: Renaissance; Ianicius; relationship with others; poetry; biography.

Dla ludzi renesansu należących do res publica litteraria ważna była nie tylko znajomość trzech języków starożytnych czy możliwość prowadzenia zażartych dysput, ale także „,zwyczajna” ludzka przyjaźń. Przyjmowała ona różne formy, zależne od charakterów zaprzyjaźnionych osób i od społecznego otoczenia. Dwór wymagał innych form towarzyskich, niż akademia lub kolegium uniwersyteckie. Jednak potrzeba przyjaźni - często tylko intelektualnej - jest wyraźna ${ }^{1}$.

Często o przyjaźń zabiegano, starano się wejść w bliskie stosunki z drugą osobą. Takie relacje należy jednak wyraźnie odróżniać od układów klienckich pomiędzy najczęściej artystą a hojnym (lub mniej hojnym) mecenasem, bowiem w nich występuje relacja nierównorzędna. Przyjaźń, przynajmniej w naszym współczesnym rozumieniu, oznacza relację dobrowolną, równorzędną i obustronną. Nie wyklucza to wszak sytuacji, kiedy jedna ze stron wnosi większy wkład.

\footnotetext{
${ }^{1}$ Warto polecić zbiór studiów: Körkel, Licht, Wiendlocha 2001, chociaż jego zakres chronologiczny jest znacznie szerszy. O środowisku artystycznym w dobie renesansu pisze Chastel (2001); ważny do badań nad przyjaźnią w aspekcie historycznym jest zbiór studiów: Stern-Gillet, Gurtler 2014, przy czym artykuły zawarte w tym tomie sięgają aż po epokę oświecenia. Najnowsza i interdyscyplinarna pozycja w nauce polskiej: Marciniak, Olechowska 2016.
} 
O przykłady nietrudno: Wawrzyniec Korwinus, śląski humanista przez wiele lat związany z Akademią Krakowską, kiedy zaszła konieczność wniósł kaucję za zamieszanego w bójkę studenta Stanisława Sauera i poręczył za niego przed sądem rektorskim². Oczywiście, przyjaźń nie zawsze musiała zostać potwierdzona w tak dramatycznych okolicznościach. We Wrocławiu około 1495 r. zawiązał się krąg humanistów, w którym znalazł się także Korwinus ${ }^{3}$. Humaniści nie tylko dyskutowali ze sobą, ale także zawierali przyjaźnie. Nie były to przyjaźnie dworskie, ale raczej intelektualne i powstałe w tym samym środowisku4

Przyjaźnie zawarte przez Korwinusa pozwalały przekraczać podziały polityczne i przeciwstawne interesy. Gdy inscenizował on Eunuchusa i Aulularie, zaprosił kanoników. Ci musieli podjąć decyzję, czy mogą się udać na przedstawienie. I nie o materię sztuki chodziło, ale o miejsce wystawienia, którym był wrocławski ratusz. Miasto z jednej strony, a z drugiej biskup i kapituła byli praktycznie w stałym sporze. Duchownym pozostawiono wolny wybór i ci, którzy obejrzeli sztuki, wrócili pełni uznania dla talentu i reżyserskich osiągnięć humanisty 5 .

Jeśli tyle miejsca poświęciłem nie naszemu głównemu bohaterowi, a innemu poecie, wynika to z prostego faktu: o przyjaźniach Janickiego wiemy niewiele. Polski Owidiusz nie pozostawił po sobie zbyt wiele listów, które najczęściej są dowodem zażyłości pomiędzy korespondentami. To co udaje się wyczytać z zachowanych utworów, stanowi jedynie okruch z większej całości ${ }^{6}$.

Trzeba zacząć od sprawy podstawowej: Janicki wybierał starannie przyjaciół i był im wierny: „Iudicio lectos colui constanter amicos, / Hos tantum veras credere doctus opes" (Elegia VII, 103-104). Ów przemyślany wybór - co szczególnie mocno akcentuje Ignacy Lewandowski - świadczy o dojrzałości młodego człowieka. Nie liczyło się zapewne dla niego przelotne zafascynowanie czyjąś osobowością lub jej popularność. Natomiast trudno rozstrzygnąć, czy na jego decyzje przemożny wpływ wywierała choroba. Przyjaciele byli dla chorego człowieka z pewnością „prawdziwym skarbem” (verae opes) ${ }^{7}$; można jednak żywić wątpliwości, czy rzeczywiście było ich wielu. Skoro poeta był „wybredny" (jak podaje przekład Jędrkiewicza) w doborze przyjaciół, to trudno zakładać, że otaczał jego ich niemały wianuszek. Sądzę, że były to raczej nieliczne, acz wypróbowane osoby. Niestety, znamy tylko kilka nazwisk, inne osoby pozostają anonimowe.

\footnotetext{
${ }^{2}$ Barycz 1982: 92-93.

${ }^{3}$ Rott 1997: 62.

${ }^{4}$ Burke 2001.

${ }^{5}$ Odnotowano to nawet $\mathrm{w}$ aktach kapituły. Spośród literatury przedmiotu należy wymienić: Lewański 1981: 202, 506-507; Dola 1983: 240-245, 283; Bering 1995: 68-69; Rott 1997: 60-61.

${ }^{6}$ Niekompletność źródeł do poznania duchowej sylwetki poety zaznacza Lewandowski (2001, 2007).

${ }^{7}$ Lewandowski 2001: 234.
} 
Kolejne pytanie, być może niezbyt trafnie postawione, to czy dla Janickiego istnieli przyjaciele ważniejsi i mniej ważni? Czy może traktował wszystkich w jednakowy sposób? Szukając odpowiedzi badacz staje bezradnie, a wynika to po części z braku źródeł. O szczątkowej spuściźnie listowej już była mowa, a zatem trzeba szukać innych świadectw. Obszerny zbiór akt do dziejów Polski z I połowy XVI w. Acta Tomiciana, w dużym stopniu bazujący na materiałach zebranych przez Stanisława Górskiego (tzw. Teki Górskiego) ${ }^{8}$, który był jednym z przyjaciół Janickiego ${ }^{9}$, niestety nie przynosi żadnych informacji o życiu poety. Być może sytuacja ta ulegnie zmianie, gdyż istniejące osiemnaście tomów obejmuje lata 1507-1536. Kolejne materiały czekają jeszcze na opublikowanie.

Pozostaje zatem analiza twórczości Janickiego. Do tego zadania należy jednak podchodzić w sposób ostrożny. I nie o samego poetę chodzi, ale raczej o renesansową manierę podkreślania wielkości i wyjątkowości, którą Jakub Burckhardt trafnie nazwał „,nowoczesną sławą"10. W ten sposób myślenia wpisuje się także pragnienie pozyskania przyjaźni osoby stojącej wyżej w hierarchii społecznej, bardziej znanej czy doświadczonej. Zapewne takie mogły być motywy bliskiej relacji pomiędzy Janickim a Hozjuszem. Wiadomo bowiem, że Janicki wyraźnie zabiegał o przyjaźń z nim. Jednocześnie poeta jest przekonany, że na przyjaźń Hozjusza zasługuje ${ }^{11}$. Ten ostatni wprawdzie nie osiągnął jeszcze najwyższych godności, ale był już dobrze zapowiadającym się kanonikiem krakowskim. O jego randze może świadczyć określenie go mianem przyjaciela przez samego Dantyszka. Pisze on bowiem w oficjalnym liście z 1536 r. do ówczesnego biskupa krakowskiego Jana Latalskiego: „Rogo item, ut prius quam versus istiusmodi transcribantur, $\mathrm{D}^{\text {tio }} \mathrm{V}$. illos singularissimo amico meo, dno Stanislao Hosio, legendos tradat meoque ab eo nomine postulet, ut si quid vel mutandum vel addendum censerit..."12. Te słowa potwierdzają wyjątkową pozycję Hozjusza, który dwa lata później został sekretarzem królewskim.

Bliska znajomość z Hozjuszem i osiągnięte przez niego stanowisko zapewne ułatwiły poecie zyskanie przyjaźni ze strony Łazarza Bonamica ${ }^{13}$. W obu przypadkach posłużył się Janicki swoim nieprzeciętnym talentem poetyckim. I Hozjusz, i Bonamico byli adresatami wierszy. Taki sposób postępowania jest

${ }^{8}$ Acta Tomiciana zaczął wydawać jeszcze w połowie XIX w. Tytus Działyński; od tomu XIV wydanego w 1952 r. obowiązuje współczesna koncepcja edytorska. Podstawę rękopiśmienną edycji omówił szczegółowo Marciniak (1983).

${ }^{9}$ Lewandowski 2001: 234.

${ }^{10}$ Burckhardt 1961: 78-83, 174-180.

${ }^{11}$ Lewandowski 2001: 234-235.

${ }^{12}$ Acta 1999: 106.

${ }^{13}$ Lewandowski 2001: 235 . 
charakterystyczny dla twórców doby renesansu, kiedy to zgrabny utwór otwierał serca (a często i sakiewki) odbiorców ${ }^{14}$.

Do Hozjusza udaje się Muza, która w imieniu poety prosi o przyjaźń. Czytelnika uderza przede wszystkim postawa Janickiego, który nie ukrywa, że liczy na nią, samemu stawiając się niżej od adresata. Widać to wyraźnie w następujących wersach:

Ianicium tibi trado meum, quod tempore multo

A superis vana quaesiit ille prece.

(V, 39-40)

W podobny sposób na nierówny stosunek zwracają uwagę i inne fragmenty:

Unus abest votis Hosius cumuloque meorum,

Qui prior ante alios conciliandus erat.

(V, 25-26)

Perpetuo tuus esse cupit venerator et optat,

Ut sit amicitiae pars quatocumque tuae.

Magna petit, fateor, sed apud te nulla repulsa est,

Magna, sed esse tamen forsan inique neges.

$(\mathrm{V}, 41-44)$

Z pewnością Janicki jest świadomy dystansu pomiędzy nim a dobrze zapowiadającym się dyplomatą i dostojnikiem kościelnym ${ }^{15}$. Mimo to żywi nadzieję, że uda się nawiązać relację równoprawną:

Desino. Semper ama iuvenem te semper amantem,

Sospes et ut possis semper amare, vale!

$(\mathrm{V}, 57-58)$

To wezwanie jest zobowiązaniem, a zatem Janicki ustami Muzy spodziewa się długiej i owocnej relacji. Czy tak było rzeczywiście, tego nie wiemy. Warto porównać wiek obu korespondentów: elegia powstała jeszcze przed wyjazdem poety do Włoch, a zatem przed 1538 r. ${ }^{16}$; Hozjusz liczył sobie trzydzieści cztery lata, a Janicki dwadzieścia dwa. Taka różnica nie jest przeszkodą, chociaż Hozjusz miał o wiele większe doświadczenie życiowe i obycie w kręgach dworskich. Natomiast niewiadomo, jak dalej układała się przyjaźń między humanistami: Hozjusz szybko piął się po szczeblach kariery kościelnej, a Janicki pozostał poetą.

\footnotetext{
${ }^{14}$ Burckhardt 1961: 79, 82-83; Burke 2001: 164-169. Na uwagę zasługuje zdanie: „Pochwał oczekiwano również od poetów” (s. 168). Należy jednak rozróżniać relacje typu artysta-mecenas od relacji przyjacielskich spotykanych na dworach.

${ }^{15}$ Lewandowski (2001: 234-235) tylko częściowo omawia tę sytuację.

${ }^{16}$ Część badaczy sądzi, że elegia ta powstała w 1540 r., dopiero po powrocie poety z Włoch. Nie zmienia to jednak rozpiętości wieku pomiędzy obu postaciami. Cf. Janicki 1966: 362.
} 
Jedno jest pewne: dzięki Hozjuszowi Janicki uzyskał pomoc i wsparcie u Łazarza Bonamica. Ten drugi był postacią znaną i znaczącą. Z psychologicznego punktu widzenia nie można mówić o równorzędności obu osób. Elegia zaadresowana do uczonego wyraźnie wskazuje na podrzędną pozycję Janickiego. On prosi, błaga, a nawet jak pisze „kornie upada [...] do stóp” („Proiecta ecce tuos volvitur ante pedes" VIII, 68). Nie wynika to tylko z dystansu społecznego, ale w pełni wpisuje się w szeroko znany w renesansie model pochwał i zyskiwania względów ${ }^{17}$.

Nawet pobieżnie analizując elegię skierowaną do wielkiego humanisty, czytelnik zauważa, że Janicki pisze wprost o swoich zamiarach: „Causa viae, Bonamice, mihi est" (VIII, 9), po czym podkreśla swoją nikłość: jego język ma „gminne brzmienie”, a on jako chłopskie dziecko jest podejrzliwy i nieśmiały. Niejako przy okazji, poeta wygłasza stereotypową pochwałę Italii, gdzie króluje prostota i ogłada ${ }^{18}$ :

Candor et urbanae sine fastu gratia mentis

Regnat, in hoc ipso fertur et orta solo.

(VIII, 21-22)

Podmiot liryczny może nieco przesadnie podkreśla swoją niską kondycję. Poczucie dystansu wynika nie tylko z różnic społecznych, ale przede wszystkim ze stopnia wybrania przez Muzy. Janicki trzeźwo ocenia, że on dopiero zaczyna się z nimi zaprzyjaźniać, a Bonamicus jest ich wybrańcem. W przeciwieństwie do elegii skierowanej do Hozjusza, gdzie Muza wzywa do odwzajemnienia uczuć, kierując wezwanie do uczonego humanisty poeta nie jest pewny, czy jego starania odniosą zamierzony skutek:

Haec tibi semper erit constans et sospes apud me,

Sive tibi gratam sensero sive nihil.

(VIII, 71-72)

Szczęśliwie dla Janickiego Bonamicus otoczył go opieką. Najdobitniejszym przykładem jest jego postawa w sporze poety z Kmitą. Jak wiadomo, Kmita otrzymywał raporty z Padwy, w których zachowanie Janickiego przedstawiano w niekorzystnym świetle. Przypuszcza się, że sprawcą tych intryg był kolejny przyjaciel poety - sam Stanisław Orzechowski. Dopiero zdecydowanie pozytywna opinia wyrażona przez Bonamica w liście do Kmity zakończyła tę nieprzyjemną dla Klemensa sytuację ${ }^{19}$. O jej ciężarze gatunkowym świadczy ko-

\footnotetext{
${ }^{17}$ Burckhardt 1961: 203-204; Curtius 1997: 90-92, 184-187.

${ }^{18}$ Przykłady takich pochwalnych sądów przytacza Burckhardt (1961: 191-204).

${ }^{19}$ Lewandowski 2001: 236.
} 
lejny dwuwers. Warto jednak podkreślić, że Janicki nie wymienia tam nazwiska swojego wroga ${ }^{20}$. To bez wątpienia szlachetny rys charakteru poety.

Nunc tua suspicio me torquet et hostis, eandem

Qui tibi materia firmat alitque tua.

(Tr. III, 27-28)

Opisywana sytuacja jest szczęśliwa także dla badaczy, którzy wreszcie spotykają namacalny dowód pomocy okazywanej Janickiemu. Można z dużym prawdopodobieństwem założyć, że poeta orientując się, że atmosfera wokół niego się zagęszcza, poprosił o wstawiennictwo swojego mistrza. Mistrza, czy przyjaciela? Sądzę, że bardziej mistrza, niż przyjaciela ${ }^{21}$. Warto zatem sprawdzić, jak Klemens zwraca się do Bonamica w innych utworach. Tristia VI zaczynają się od przejmującego wyznania poety, że czuje się dłużnikiem niezdolnym do spłaty. Tak wiele dobrodziejstw spotkało go ze strony padewskiego profesora.

Lazare, conturbor, quoties considero, quantum

Debeat officiis haec mea vita tuis,

Non secus ac alieno aliquis cum mersus in aere est

Et se solvendo non putat esse parem.

Nam mea quae fuerit vesania, posse reponi

Si rear a nobis tot bene facta tibi?

(Tr. VI, 1-6)

Jest to zatem wyznanie wdzięczności, najpiękniejszy sposób podziękowania na jaki może zdobyć się poeta. Czytelnika uderza także drobiazgowe wyliczenie różnych form wsparcia otrzymanych od Bonamica. Mowa bowiem o zatroszczeniu się o lekarza, ,zasileniu groszem”, czy o wyposażeniu na drogę do Polski. Nie zabrakło oczywiście podziękowania za pomoc w uzyskaniu zaszczytnego tytułu. Janicki jest gotów czcić swego nauczyciela jako Boga, ale ponieważ tego zabrania religia (to ciekawy rys życia duchowego poety) oddaje mu się na własność: „habebis: Me [...] tuum” (Tr. VI 69-70). Jest to z pewnością wyznanie przyjacielskie, ale wpisuje się ono także w feudalny obyczaj hołdu lennego. Pomiędzy suzerenem a wasalem powstawała relacja wzajemnej zależności, zewnętrznie manifestująca się bogatym ceremoniałem ${ }^{22}$. Warto przypomnieć, że bizantyjski protokół dyplomatyczny posiadał bardzo rozbudowane formy

${ }^{20}$ Lewandowski (2001: 236) odnotowuje ów fakt, lecz nie rozwija szerzej tego wątku.

${ }^{21}$ Spotyka się tutaj z zagadnieniem niezwykle ważnym dla przyjaźni, czy jest ona możliwa tylko w relacjach „równy z równym”, czy też może istnieć w nierównych społecznie układach; pokrótce dyskusję nad tym problemem omawia Konstan (1997: 3-8); w realiach historycznych Styka (2016) przedstawia znaczenie przyjaźni między równymi.

${ }^{22}$ Zwięźle omawia ceremoniał lenny Manteuffel (1978: 121-123). Rozbudowany ceremoniał dworski charakteryzuje Huizinga (1992: 66-70). Cf. Dalewski 2009. Najistotniejszą pracę w ostatnich latach bez wątpienia napisał Althoff (2003); ważne rozpoznania poczynił Müller (2010). 
zewnętrzne, do których należał pocałunek i wymiana darów. Są to oczywiście zjawiska o wiele wcześniejsze, ale zapewne ich ślad pozostał w świadomości potomnych ${ }^{23}$.

W mojej analizie poprzestanę jedynie na tych dwóch osobach, które dla Janickiego były ważne. Wiadomo, że poeta przyjaźnił się także z innymi osoba$\mathrm{mi}$, ale te relacje nie przetrwały próby czasu ${ }^{24}$. Należy powrócić do zagadnień zasygnalizowanych na wstępie. Jak w świetle rozmaitych koncepcji - przede wszystkim ówczesnych i wcześniejszych - wyglądała przyjaźn Janickiego? Czy budował on swoje relacje na zasadzie równoprawności, czy był stroną dominującą, czy bardziej pasywną?

Sądzę, że punktem wyjścia powinno być stwierdzenie Cycerona z Leliusza (69) „Sed maximum est in amicitia parem esse inferiori”. I nie chodzi tu o obniżanie rangi poety, który wobec swoich przyjaciół najczęściej stał niżej w hierarchii społecznej i był od nich młodszy. A zatem to on powinien wiecej zyskiwać. Nie kłóci się to między innymi z poglądami Seneki Młodszego, który w VI liście nie stwierdza wprawdzie wprost, ale można pośrednio z niego wyczytać, że prawdziwa przyjaźń nie wymaga równości intelektualnej. Przyjaciele dzielą się między sobą dobrami duchowymi ${ }^{25}$. Cyceron wskazywał na rolę cnoty i jej kształtowania w podtrzymywaniu przyjaźni; bez wątpienia tu starsi i możniejsi powinni być dla Janickiego wzorcami. Czy sprostali temu zadaniu? Nie czuję się na siłach, by na tak postawione pytanie odpowiedzieć. I wreszcie prawdziwą zagadkę stanowi brak jakże popularnego Horacjańskiego motywu przyrównującego przyjaciela do połowy duszy - „Amicus est animae dimidium” (Carm. $1,3,8)$. Nie sposób odpowiedzieć, dlaczego znający doskonale starożytną poezję Janicki nie nawiązał do tej myśli.

Ale przecież są jeszcze inne przymioty powszechnie łączone z przyjaźnią: życzliwość, wdzięczność a także stałość ${ }^{26}$. Tę pierwszą szczególnie podkreślano w antyku. Myśl tę zmodyfikował w średniowieczu Tomasz z Akwinu do przymiotów przyjaźni dołączając caritas. Ten szczególny rys jest widoczny w relacji Boga do człowieka. Bóg został nawet określony jako cartor $^{27}$. Można jednak bez trudu wyobrazić sobie relację, w którą jedna strona wnosi więcej, a druga więcej bierze i obie mimo tej „nierówności” są pełnoprawnymi przyjaciółmi.

Zapewne taka była natura relacji Klemensa z osobami, które wybrał sobie „wybrednie” (iudicio) na przyjaciół. Wdzięczność im okazywana jest łatwiejsza do wyczytania z utworów i innych źródeł. Ale to temat na zupełnie inny artykuł.

\footnotetext{
${ }^{23}$ Wasilewski 1966.

${ }^{24}$ Lewandowski 2001: 240.

${ }^{25}$ Wesołowska 2010: 37-38.

${ }^{26}$ Przymioty przyjaźni analizuje Styka (2016), wskazując na ich zróżnicowanie i próbuje znaleźć ich intelektualne źródła.

${ }^{27}$ Kerr 2014: 249.
} 


\section{BIBLIOGRAFIA}

\section{Źródła}

Acta Tomiciana 1999: Acta Tomiciana. Tomus octavus decimus, coll. V. Urban, A. Wyczański, supplevit et ed. R. Marciniak, Kórnik 1999.

Janicki 1966: K. Janicki, Carmina. Dzieła wszystkie, wyd. J. Krókowski, kom. J. Mosdorf, Wrocław-Warszawa-Kraków 1966.

\section{Opracowania}

Althoff 2003: G. Althoff, Die Macht der Rituale. Symbolik und Herrschaft im Mittelalter, Darmstadt 2003.

Barycz 1982: H. Barycz, Śląsk w polskiej kulturze umysłowej, Katowice 1982.

Bering 1995: P. Bering, Das Publikum der Elegienkomödie und der humanistischen Komödie im spätmittelalterlichen Polen, „Medium Aevum Quotidianum” 33 (1965), 63-69.

Burckhardt 1961: J. Burckhardt, Kultura odrodzenia we Włoszech. Próba ujęcia, Warszawa 1961.

Burke 2001: P. Burke, Dworzanin, [w:] Człowiek renesansu, E. Garin (red.), Warszawa 2001, $145-175$.

Chastel 2001: A. Chastel, Artysta, [w:] Człowiek renesansu, E. Garin (red.), Warszwa 2001, 251281.

Curtius 1997: E.R. Curtius, Literatura europejska i łacińskie średniowiecze, Kraków 1997.

Dalewski 2009: Z. Dalewski, Pedibus vestris provulutus. Znaczenie gestu ukorzenia w kulturze politycznej średniowiecza, [w:] Persona. Gestus Habitusque. Insignium. Zachowania i atrybuty jako wyznaczniki tożsamości społecznej jednostki w średniowieczu, J. Banaszkiewicz, J. Maciejewski, J. Sobiesiak (red.), Lublin 2009, 67-78.

Dola 1983: K. Dola, Wrocławska kapituła katedralna w XV wieku. Ustrój-skład osobowy-dziatalność, Lublin 1983.

Garin 2001: Człowiek renesansu, E. Garin (red.), Warszawa 2001.

Huizinga 1992: J. Huizinga, Jesień średniowiecza, przeł. T. Brzostowski, Warszawa 1992.

Kerr 2014: F. Kerr, Thomas Aquinas Charity as Friendship, [w:] Ancient and Medieval Concepts of Friendship, S. Stern-Gillet, G.M. Gurtler (ed.), New York 2014, 245-267.

Konstan 1997: D. Konstan, Friendship in the classical world, Cambridge 1997.

Körkel, Licht, Wiendlocha 2001: Mente Amoris Ligati. Lateinische Freundschaftsdichtung und Dichterfreundschaft in Mittelalter und Neuzeit, B. Körkel, T. Licht, J. Wiendlocha (ed.), Heidelberg 2001.

Lewandowski 2001: I. Lewandowski, Freundschaft und Freunde in den Werken des Clemens Ianicius, poeta laureatus (1516-1543), [w:] Mentis amore ligati, B. Körkel, T. Licht, J. Wiendlocha (ed.), Heidelberg 2001, 233-241.

Lewandowski 2007: I. Lewandowski, Klemens Janicki (1516-1543) - polski Owidiusz nad Warta zrodzony, [w:] Polonia Latina. Szkice o literaturze łacińskiej w dawnej Polsce, Gniezno 2007, 47-60.

Lewański 1981: J. Lewański, Dramat i teatr średniowiecza i renesansu w Polsce, Warszawa 1981.

Manteuffel 1978: T. Manteuffel, Historia powszechna. Średniowiecze, Warszawa 1978.

Marciniak, Olechowska 2016: De Amicitia. Transdisciplinary Studies in Friendship, K. Marciniak, E. Olechowska (ed.), Warsaw 2016.

Marciniak 1983: R. Marciniak, „Acta Tomiciana” w kulturze politycznej Polski okresu odrodzenia, Warszawa-Poznań 1983.

Müller 2010: J-D. Müller, Kulturwissenschaft historisch. Zum Verhältnis von Ritual und Theater im späten Mittelalter, [w:] Mediävistische Kulturwissenschaft. Ausgewählte Studien, BerlinNew York 2010, 111-134.

Rott 1997: D. Rott, Wawrzyniec Korwin w kręgu wrocławskich miłośników antyku, [w:] Tradycje kultury antycznej na Ślasku, J. Rostropowicz (red.), Opole 1997, 57-71. 
Stern-Gillet, Gurtler 2014: Ancient and medieval concepts of friendship, S. Stern-Gillet, G.M. Gurtler (ed.), New York 2014.

Styka 2016: J. Styka, „Inter amicos inter aequales...” The Reflections of Sidonius Apollinaris (Fifth Century AD) on the Elite Consciousness of Gallo-Roman Nobles in the Period of Barbarian Invasions, [w:] K. Marciniak, E. Olechowska (ed.), Warszawa 2016, 351-368.

Wasilewski 1966: T. Wasilewski, Bizantyńska symbolika zjazdu gnieźnieńskiego i jej prawno-polityczna wymowa, „Przegląd Historyczny”, 57 (1966), z. 1, 1-14.

Wesołowska 2010: E. Wesołowska, Przyjaźń podtug Lucjusza Anneusza Seneki. Kilka spostrzeżeń, „Poznańskie Studia Polonistyczne. Seria Literacka”, 17 (37) 2010, 33-41.

\section{DIE FREUNDSCHAFT IN IANICIUS' LEBEN UND WERKEN}

Zusammenfassung

Im Beitrag wurde die Rolle der Freundschaft im Leben Ianicius', des neulateinischen poeta laureatus (1516-1543) erforscht. Das größte Hindernis bildet ein Quellenmangel: es werden praktisch keine Briefe erhalten. Die Forscher verfügen nur über einige Zeugnisse der Bekannten und Freunden des Dichters. Bei der Analyse der Ianicius' Werken sollte man an eine RenaissanceÜbertreibungsmanier denken. Trotz dieser Beschränkungen kann man die wichtigsten für Ianicius Personen identifizieren. Zu ihnen gehörte auch Lazarus Bonamicus, der eine entscheidende Rolle in der Entwicklung der poetischen Begabung spielte. Eine andere noch nicht lösbare Frage betrifft die Natur der Ianicius' Freundschaft. War er ein aktives oder passives Mitglied in Beziehungen mit anderen? Das leider können die Forscher nicht beantworten. 